\title{
TONGA RELIGIOUS BELIEFS AND CUSTOMS ${ }^{1}$
}

WhILE itinerating recently in the southwest corner of Bandawe district we came across one of the old heathen customs which are dying out so fast all through Tongaland. One of the wives of the chief in whose village we were camped had but recently died, and the whole village was in mourning and "lying on leaves" as they put it. As I had been going into the subject of the religious beliefs of the people only a few weeks previously, the funeral rites very much interested me. The native's stock of religious beliefs is for the most part made up of his ideas about the dead, just as the spirits rather than God gather about them the larger share of heathen worship.

The Tonga conceives of the mouchi, breath, of man, as a man's soul or life-urima, umoyo. As long as there is this mouchi in a man, as long as he breathes-roatuta-he lives, ngamoyo or ngwausima. When he ceases to breathe ngwakufwa, he is dead, but that does not mean that he ceases to exist. Supposing a person should faint and his respiration apparently pause, they would say wangufwa, he died, even after the swoon had passed and he was recovered again. If from any cause the person wafwiya limu, dies once for all. even then he exists if in another state, his spirit lives on, the departed spirit being called moimu. Mrimu is properly only applicable to the spirit of the dead, although nowadays on account of the introduction of foreign, and particularly of Scriptural, ideas, the soul or spirit of the living man is

1 Reproduced from The Acorme of February, 1905. We understand that Mr. MacAlpine is about to publish in book-form the ecries of articles of which this is the find. $-\mathrm{ED}$. 
commonly referred to as the man's moimu. In his heathen state no one would ever have thought, however, of saying to another, "Mwe mzimu mo mwako,"-there is a spirit in you. Msimu (pl. asimu), correctly speaking, is only the spirit after death. The sense in which they might have spoken of a living man having a spirit, would be that he had a guardianspirit, e.g., Nde ndi msimu wamampha, I have a good spirit, meaning a good guardian-spirit who looks after him. Nde ndi mzimu uheni, would be the opposite of course, viz., that he had a bad spirit, one who did nothing for him, or even wrought against him.

The mzimu, or departed spirit, is also called by the names, chituta and chiwanda. The latter name is frequently applied also to the corpse, and many were the rites observed in connection with its interment and the preparation for it.

As death was seen to be near, some one of those who waited on the sick friend went out of the house to fwifwinthiya. This silent weeping was a sign to any about that the end was very near, and very shortly thereafter the wailing probably began and was joined in by all the relatives and friends of the deceased. Both inside the house and outside the wailing was kept up for very long, the corpse being meanwhile probably held up in the arms of wife or mother, as she sat in the desolate hut, or laid across the legs of the mourners as they sat opposite each other in the house of the dead. When this first mourning had been carried through, the corpse was laid out on a mat, and covered with a winding sheet. As the mankuru bade the mourners rise, a fresh wail would break forth as the wife or mother cried, "Oh, have you come at last to take my husband, my child, away from me?" This maskuru might be anyone in the village or from a neighbouring village, not necessarily a relative, although relatives of the dead might always call him mbale, friend, thereafter. The office of maukuru was rather coveted, as the one who first began to prepare the dead for burial on that account became the chimbwi whose services were always sought when an offering was to be made to the dead. The chimbwi was not invited to undertake the preparation of the corpse for burial : to have done so would have brought about strife, as 
the person asked to do this service would have turned about and said, Do you think I have brought about his death that you ask me to see to his burial? The service was always voluntarily rendered. The word chimbwi properly means a hyena, and it was applied to the chief mzukuru, because he first had approached the dead body, thus showing that he had no fear of a corpse.

The first person to whom the death would be formally announced was the chief of the village, while messengers were on their way to tell distant relatives, or if the deceased was a person of importance, to inform neighbouring chiefs. None of these latter, nor for that matter the Friends living at a distance, were told without at the same time a mphumunthu, which might be a fowl or a hoe or some other article, being presented to them. When the friends came, a present, or payment we should rather call it, had to be made to them, the amount given sometimes, particularly at the death of a woman, being considerable. When they were satisfied, they would come and view the body, giving permission for its burial thereafter.

While the death was being announced the chimbwi and other asukuru washed the body and then rubbed it over with oil, clothing it finally with the graveclothes, finer probably than the dead had been in the habit of wearing in life. If the friends of the dead lived in the same village and the "death dues" were quickly paid to them, the chimbwi was at liberty to close the door of the hut after him on completing these first preparations for burial. If the friends had not arrived, or if they refused to accept the payment made to them, being dissatisfied with the smallness of it, then the door of the hut might not be shut, and could not be shut till a proper settlement had been made. The strife went on sometimes for several days, and I have known of burial being refused within quite a few years back while the haggling went on. Christians now refuse to make these payments altogether, and sometimes have to put up with a good deal of trouble where public opinion has not yet come round to their way of it.

If the death happened in the morning and everything had 
been arranged to the satisfaction of all, burial probably would take place the same day, a custom that would commend itself to all living in a hot country. The people had a feeling, however, that they ought not to do anything to give the impression that they were hurrying through these funeral ceremonies and cared little for their late friend. Burial was sometimes on this account delayed till the next day.

A. G. MacAlpine. 